\title{
Nutritional and anti-nutritional characteristics of the larva of Oryctes monoceros
}

\author{
Ifie, Idolo ${ }^{1^{*}}$ and Emeruwa, Chibuisi, Henry ${ }^{2}$ \\ Department of Animal Science, Faculty of Agriculture, Delta State University, Asaba Campus, \\ Asaba, Delta State, Nigeria. ${ }^{1}$ E-mail: idifie@yahoo.com. Phone no+2348038272365 \\ Department of Animal Science, Faculty of Agriculture, University of Ibadan, Oyo State, \\ Nigeria $^{2}$
}

\begin{abstract}
The proximate analysis and amino acid profile of the larva of Oryctes Monoceros were investigated. The mineral profile and antinutritional factors were also determined. A high protein content (36.45\% dry weight) was recorded with the larva containing the essential amino acids in varying proportions in the amino acid profile. An ash content of $(4.00 \%$ dry weight) was recorded containing high proportions of sodium, magnesium, iron and potassium. $(440.0 \mathrm{mg} / 100 \mathrm{~g}$, $175.0 \mathrm{mg} / 100 \mathrm{~g}, 85.00 \mathrm{mg} / 100 \mathrm{~g}, 38.40 \mathrm{mg} / 100 \mathrm{~g}$, respectively). The other mineral elements, zinc, manganese and copper were also present in smaller quantities. The result of the antinutritional factors showed that levels of phytic acid $(178 \mathrm{mg} / 100 \mathrm{~g})$, tannin $(14.3 \mathrm{mg} / 100 \mathrm{~g})$ oxalate $(2.1 \mathrm{mg} / 100 \mathrm{~g})$ all fell within acceptable levels. In addition, the larva protein had a digestibility of $58.05 \%$. The insect larva could serve as an alternative source of protein and other nutrients supplement in human and animal diet.
\end{abstract}

Keywords: Oryctes Monoceros, Proximate composition, nutritional value, antinutritional factors.

\section{INTRODUCTION}

Insects have played an important part in the history of human nutrition in Africa, Australia, Asia and the Americas. They were equally important resources for the Indians of western North America, who, like other indigenous groups, expended much organization and effort in harvesting them (Sutton, 1988). There are over 1,400 recorded edible insects (FAO, 2008) and according to DeFoliart (2002, 1989), indigenous population in many Third World countries where animal protein is scarce use 30 species of insects or more. As long as protein-energy malnutrition prevails in developing countries, the search for low cost, nutritious and easy to prepare locally available complementary foods will continue (Solomon et al., 2008). In addition, global climate change and increasing food insecurity in many parts of the developing world may put insects regularly on the menu. Most edible insects are cheap, available and can provide a good source of protein and minerals needed to complement cereal based foods consumed in the developing countries. The larva of Oryctes Monoceros is one of the insects commonly consumed in the Niger Delta regions of Nigeria. It is commonly consumed raw, boiled smoked or fried. Consequently, the objective of this study is to investigate the nutrients, minerals and anti-nutritional components of the larva. The findings will further buttress the need for the populace in the developing worlds to turn to these cheaper sources of protein to combat the problem of malnutrition.

\section{MATERIALS AND METHODS}

Live larvae of Oryctes Monoceros were collected with the assistance of the local palm wine tapers along with their feed and transported to the laboratory in a well ventilated container. The specimens were ovendried and ground for analysis at the Nigeria institute for Oil Palm Research (NIFOR) Benin City, Nigeria

Proximate analysis: The larvae were analyzed chemically according to the official methods of analysis recommended by the Association of Official and Analytical Chemists (A. O. A. C., 1990). Determinations were performed for water content, crude fiber (structural carbohydrates), fat, and mineral salts. The crude proteins were determined using Kjeldahl technique. The mineral content of the larva was determined were determined using the method described by Oshodi (1992). The insects were ashed at $550{ }^{\circ} \mathrm{C}$ in a muffle furnace for hours. The ash content was dissolved in $10 \% \mathrm{HCl}$ and made up with distilled water to $100 \mathrm{ml}$ mark in a standard flask. Some of the minerals present such as magnesium, iron, manganese, calcium, zinc, 
Agric. Biol. J. N. Am., 2011, 2(1):42-46

cadmium, copper were analyzed by alpha 4 atomic absorption spectrophotometer. Sodium and potassium were estimated by Corning 405 flame photometer (AOAC, 1990). The amino acid profile of the larva was evaluated according to the method of (Spackman et al., 1958) in a Biochrom 30 amino acid analyzer.

Determination of tannin content: the method of estimation of tannin content in extract by Joslyn (1970) was used for the determination of tannin content in the sample. Finely ground sample $(0.5 \mathrm{~g})$ was defatted with $5 \%$ ethyl for $15 \mathrm{~min}$. the tannin in the defatted sample was then extracted with methanol and the absorbance at $760 \mathrm{~nm}$ was measured.

Phytic acid determination: Phytic acid content was determined by the method described by Wheeler and Ferrel (1971) using $2.0 \mathrm{~g}$ of the dried sample. A standard curve was prepared expressing the results as $\mathrm{Fe}\left(\mathrm{NO}_{3}\right)_{3}$ equivalent.

Oxalate content determination: this was determined using the method of Day and Underwood (1986). To $1 \mathrm{~g}$ of the ground powder, $75 \mathrm{ml}$ of $15 \mathrm{~N}$ $\mathrm{H}_{2} \mathrm{SO}_{4}$ was added. The solution was carefully stirred intermittently with a magnetic stirrer for $1 \mathrm{hr}$ and filtered using Whatman No 1 filter paper. $25 \mathrm{ml}$ of the filtrate was then collected and titrated against $0.1 \mathrm{~N}$ $\mathrm{KMnO}_{4}$ solution till a faint pink colour appeared that persisted for $30 \mathrm{~s}$.

In vitro Protein Digestibility: the invitro protein digestibility of the sample was measured according to the method of Saunders et al (1973). About 250mg of the sample was suspended in $15 \mathrm{ml}$ of $0.1 \mathrm{~N} \mathrm{HCl}$ containing $1.5 \mathrm{mg}$ pepsin (1: 10,000) in a $100 \mathrm{ml}$ conical flask. The mixture was incubated at $37^{\circ} \mathrm{C}$ for 3 hours. The mixture was then neutralized with $0.5 \mathrm{~N}$ $\mathrm{NaOH}$ and treated with $4 \mathrm{mg}$ pancreatin in $7.5 \mathrm{ml}$ of $0.2 \mathrm{M}$ phosphate buffer ( $\mathrm{pH} 8$ ) containing $0.005 \mathrm{M}$ sodium azide. The mixture was incubated at $37^{\circ} \mathrm{C}$ for 24hours. About $10 \mathrm{ml}$ of $10 \%$ trichloroacetic acid (TCA) were added to the mixture to stop the reaction. The mixture was then centrifuged at 500rpm for five minutes. About $5 \mathrm{ml}$ of the aliquots from the supernatant were pippeted and analyzed for nitrogen content (AOAC, 1984). Protein digestibility was determined according to the equation.

Protein Digestibility $\%=\underline{N \text { in supernatant- enzyme } N} \times 100$ $\mathrm{N}$ in Sample.

\section{RESULTS AND DISCUSSION}

The result of the proximate analysis is presented in table 1. The fat content reported is $34.00 \%$ dry weight. Ekpo and Onigbinde (2005) reported a value of $66.61 \%$ for Rhynchophorus phoenicis. Insects vary widely in fat content. Isoptera (termites) and Lepidoptera (caterpillars) rank among the highest in fat. The fat content recorded implies that defatting would improve the concentration of other nutrients. The relatively high protein content (36.45\%) dry weight observed is an indication that this insect can be of value in man and animal diet, particularly in developing countries where the cost of convectional protein sources are expensive. Furthermore, the protein content in the larva is able to significantly contribute to the daily protein requirements of humans, which is about 23-56 g (NRC, 1974; Chaney, 2006). A relatively high carbohydrate content is observed when compared to other sources of protein from cow, milk and egg. (FAO, 1972; Singh, 2004).

Table 1: Proximate composition of the larvae of Oryctes monoceros

\begin{tabular}{|l|l|}
\hline Nutrient & Dry weight \% \\
\hline Lipid & 34.00 \\
\hline Protein & 36.45 \\
\hline Ash & 4.00 \\
\hline Crude fibre & 10.50 \\
\hline $\begin{array}{l}\text { Nitrogen free } \\
\text { Extract }\end{array}$ & 15.05 \\
\hline
\end{tabular}

Results are mean of three (3) determinations

The mineral profile of the larva presented in table 2 shows that the larva contains appreciable amounts of Iron, Sodium, Magnesium, Potassium and Zinc. The high content of iron and zinc in many edible insects is of particular interest. Iron deficiency is a major problem in women's diets in the developing world, particularly among pregnant women, and especially in Africa (Orr, 1986). Vegetarians everywhere are at risk of zinc deficiency. Magnesium is needed for more than 300 biochemical reactions in the body. It helps maintain normal muscle and nerve function, keeps heart rhythm steady, supports a healthy immune blood and regulates blood sugar levels (Saris et al.,2000). Though these food elements are in the larva, the insect could be consumed along with other food and animals rich in other essential minerals to further complement the diet of this larva. The amino acid profile of the larva is shown in table 3 . The nutritional value of food largely depends on 
the quality of the protein it contains. This in turn, is determined to a great extent, by the amino acid composition. The results presented suggest that the larva is rich in essential amino acids, leucine, phenylalanine, and methionine and may well meet the minimum daily requirements (WHO, 1975.) This is particularly important as there is a need for novel protein sources owning to the increasing cost of convectional sources of protein in the third world. In addition, the cereal based diets common in developing countries could receive a boost with the inclusion of the larva in their diet. The results of the level of antinutritional factors content and protein digestibility is presented in table 4 . The tannin content recorded is within the acceptable range. Aletor, (1995) reported that high level of tannins (76$90 \mathrm{~g} \mathrm{~kg} \mathrm{Dm}^{-1}$ ) could be detrimental if consumed. Tannins usually form insoluble complexes with protein thereby interfering with their bioavailability and high tannin in diets is ascribed to its astringent property, which is a consequence of its ability to bind with proteins of saliva and mucosal membranes. The phytic acid content of $178 \mathrm{mg} / 100 \mathrm{~g}$ reported for Oryctes monoceros larva is lower than values of $350 \mathrm{mg} / 100 \mathrm{~g}$ and $293 \mathrm{mg} / 100 \mathrm{~g}$ obtained by Nafisa et al., (2008) for boiled and fried locust flour respectively. Similarly, Vijayakumari et al (1997) reported that $513 \mathrm{mg}$ of phytic acid is present in $100 \mathrm{~g}$ of $P$. chilensis. According to Oke, (1969), a phytate diet of $1-6 \%$ over a long period decreases the bioavailability of mineral elements in mono gastric animals. It binds to mineral elements such as calcium, zinc, manganese, iron and magnesium to form complexes that are undigestable, thereby decreasing the bioavailability of these elements for absorption (Erdman, 1979). The result obtained in this study implies that the phytic levels present in the larva pose no health risk. The oxalate level of $2.1 \mathrm{mg} / 100 \mathrm{~g}$ recorded in this work is lower than the value reported by Omotosho, (2005) for C. armatum. According to Ladeji (2004), oxalate can bind to calcium present in food thereby rendering calcium unavailable for normal physiological and biochemical role such as the maintenance of strong bone, teeth, cofactor in enzymatic reaction, nerve impulse transmission and as clotting factor in the blood. The lower value of oxalate recorded suggests that the nutritive value Oryctes monoceros would be impaired to a comparatively lesser extent. The in vitro protein digestibility of $58.05 \%$ recorded is higher than reported values of $49.89 \%$ and $41.13 \%$ by Nafisa et al., (2008) for boiled and fried locust respectively. Similarly, De Conconi et al. (1984) reported over 64\% in protein digestibility of some edible insects evaluated in Mexico. Generally, insect proteins are known to be of good digestibility containing some essential amino acids in appreciable amounts and the limiting amino acids can easily be supplemented with plant based protein sources

Table 2: Mineral profile of Oryctes monoceros larva

\begin{tabular}{|l|l|}
\hline Mineral & $\begin{array}{l}\text { Composition, } \\
\mathbf{m g} / \mathbf{1 0 0 g}\end{array}$ \\
\hline Potassium & 38.40 \\
\hline Sodium & 440.0 \\
\hline Calcium & $\mathrm{ND}$ \\
\hline Magnesium & 175.00 \\
\hline Zinc & 7.00 \\
\hline Cadmium & $\mathrm{ND}$ \\
\hline Manganese & 1.21 \\
\hline Iron & 85.00 \\
\hline Copper & 1.00 \\
\hline
\end{tabular}

The values represent the mean of three determinations. ND: not detected

Table 3. Amino acid profile of the larva of Oryctes monoceros

\begin{tabular}{|l|l|}
\hline Amino acid & $\begin{array}{l}\text { Composition }(\mathrm{g} / 100 \mathrm{~g}) \\
\text { protein }\end{array}$ \\
\hline Alanine & 2.34 \\
\hline Lysine & 2.83 \\
\hline Arginine & 4.35 \\
\hline Trytophan & 2.10 \\
\hline Tyrosine & 2.20 \\
\hline Isoleucine & 3.04 \\
\hline Valine & 2.64 \\
\hline Histidine & 2.88 \\
\hline Aspartic acid & 7.18 \\
\hline Serine & 3.06 \\
\hline Threonine & 2.90 \\
\hline Proline & 2.30 \\
\hline Glutamic acid & 11.24 \\
\hline Cysteine & 2.08 \\
\hline Phenyalanine & 4.65 \\
\hline Glycine & 2.06 \\
\hline Methoinine & 2.08 \\
\hline Leucine & 6.30 \\
\hline
\end{tabular}


Table 4: The antinutritional factors content and protein digestibility of the Oryctes monoceros larva.

\begin{tabular}{|l|l|}
\hline Parameters Determined & Amount \\
\hline Tannin $\mathrm{mg} / 100 \mathrm{~g}$ & 14.3 \\
\hline Phytic acid $\mathrm{mg} / \mathrm{100 \textrm {g }}$ & 178 \\
\hline Oxalate acid mg/100g & 2.1 \\
\hline Protein digestibility(\%) & $58.05 \%$ \\
\hline
\end{tabular}

Values are means of triplicate samples

CONCLUSION: The results obtained from this study shows that the larva of Oryctes monoceros is a good source of protein and other nutrient supplements. An increase in world-wide of the mass of this larva and other edible insects through cultivation with modern techniques would decrease the pressure exerted on the convectional sources of proteins. Consequently, it is recommended that its consumption should be encouraged particularly among the poor sections of populations throughout the developing countries, most especially in Africa, to alleviate the problem of nutrient/protein malnutrition.

\section{REFERENCES}

AOAC. (1990). Methods of the Association of Official Chemists. Official Methods of Analysis, 15th ed., Virginia Assoc. Official Analytical Chemists, USA. 1141

Chaney, S.G (2006). Principles of Nutrition I: Macronutrients. In: Devlin, T.M. (Eds.). Textbook of Biochemistry, with Clinical Correlation. 6th Edn. John Wiley and sons, New York, pp: 1071-1090

Day, R.A, and Underwood, A.L (1986) Qualitative Analysis. 5th Ed. New Delhi, India: Prentice Hall Publications. 701.

DeFoliart, G.R (1989). The human use of insects as food and as animal feed. Bull. Ent. Soc. Am. 35: 22-35.

DeFoliart, G.R (2002). The Human Use of Insects as a Food Resource: A Bibliographic Account in Progress (http://www.food-insects.com/book)

DeConconi, J.R.E., Moreno, J.M.P., Mayaudon, C.M., Vadde, F.R., Perez, M.A., Rodriguez, H.B (1984). Protein content of some edible insects in Mexico. J. Ethnobiol. 4: 61-72.

Ekpo, K.E, and Onigbinde, A.O (2005) Nutritional Potentials of the larva of Rhynchophorus phoenicis $(F)$. Pak. J. Nutr. 4(5): 287-290.
Erdman, G (1979). Phytic acid and zinc bioavailability in human nutrition. J. Agric. Food Chem. 27 (3): 11-14.

FAO, (1972) Amino acid content of food and biological data on proteins. A report of $\mathrm{FAO} / \mathrm{UN}$ joint Committee, Rome. NO.74.

FAO, (2008) Forest insects as food: Humans bite back. Forest News Vol. 22: 1 (www.fao.org/world/regional/rap/tigerpaper/Paper/TP3 5_1_FN.pdf)

Fasoranti, J.O and Ajiboye, D.O (1993) Some edible insects of Kwara State, Nigeria .Am. Entomologist.; 39 (2):113-116.

Joslyn, A.M (1970) Methods in Food Analysis. Physical, Chemical and Instrumental Methods of Analysis. 2nd Ed. San Francisco, New York: Academic Press : 1-3.

Ladeji, O., Akin, C.U, and Umaru, H.A (2004). Level of antinutritional factors in vegetables commonly eaten in Nigeria. Afr. J. Nat. Sci. 7: 71-73.

Nafisa, M., Hassan, E.I., Hamed, S.Y., Hassan, A.B., Mohamed, M.E. and Babiker, E.E (2008) Nutritional Evaluation and Physiochemical Properties of Boiled and Fried Tree Locust. Pakistan Journal of Nutrition 7 (2): 325-329.

NRC, (National Research Council), (1974). Recommended daily allowances. United States Food and Nutrition Board, National Academy of Science, Washington D.C., USA.

Orr, B (1986). Improvement of women's health linked to reducing widespread anemia. Int. Health News 7:3.

Omotoso, O.T (2005). Chemical composition and nutritive significance of the land crab Cardisoma armatum (Decapoda) Afri. J. of Appli. Zoo and Enviro. Biol. 7: 68-72.

Oke, O.L (1969). Chemical studies on the more commonly used vegetables in Nigeria. Afr. Sci. Ass. 11: 42-48.

Oshodi, A.A. (1992) Proximate composition, nutritionally valuable minerals and functional properties of Adenopus breviflorus benth seed flour and protein concentrate. Food Chem. 45(2):79-83.

Saris, N.E., Mervaala, E., Karppanen, H., Khawaja, J.A and Lewenstam A.( 2000) Magnesium: an update on physiological, clinical, and analytical aspects. Clinica Chimica Acta ; 294:1-26.

Sauders, R.M., Conner, M.A., Booth, A.V., Bickott, E.M and Kohler G.O (1973). Measurement of digestibility of alfalfa proteins concentrate by in vivo and in vitro methods. J. Nutr. 103: 530-535.

Singh, S.P (2004). Practical Manual of Biochemistry. $5^{\text {th }}$ Edn. CBS Publishers, New Delhi. 
Agric. Biol. J. N. Am., 2011, 2(1):42-46

Solomon, M., Ladeji, O and Umoru, H (2008) Nutritional Evaluation Of The Giant Grasshopper ( Zonocerus variegatus) Protein And The Possible Effects Of Its High Dietary fibre On Amino Acids And Mineral Bioavailability. Afri J. of Food Agric.Nut. and Development 8(2) 238-248.

Spackman, D.H., Moore, S. and Stern, W.H (1958). Automatic recording apparatus for use in chromatography of amino acids. Anal Chem. 30: 1190.

Sutton, M.O (1988). Insects as food: Aboriginal entomophagy in the great Basin. Ballena Press
Atthropo [ Papers No 33] Ballena Press, Menlo Park, California. 1-115.

Vijayakumari, K., Siddhuraju, P and Janardhanan, K (1997) Effect of domestic processing on the levels of certain antinutrients in Prosopis chilensis seeds (Molina) Stunz. Food Chemistry 59: 367-371.

Wheeler, E.I and Ferrel, R.E (1971). Methods for phytic acid determination in wheat and wheat fractions. J. Cereal Chem. 48: 312-320.

WHO, (1975). Energy and Protein Requirements. WHO Technical Report No. 522 